\title{
NOTES ON THE GEOLOGY AND WATER SUPPLY OF THE INTERIOR OF NEW SOUTH WALES.
}

\section{Plate XXV.}

\section{By Rev. J. Milne Curran, F.G.S.}

The subject of water supply for the interior is occupying a considerable amount of attention at present. Much of what has been suggested on the subject is of no practical value from the fact that comparisons are instituted with other countries where the existing physical conditions are very different. The anomalies, (so called) which we find so often in Australian Geology and Botany present themselves in full force when we come to deal with the question of a water supply for the interior. In other countries the rivers grow and increase as they flow, while in the interior of the colony they (with two exceptions) grow less. When we study a map of the Thames or Ganges we may mark the source of the river and say that a spring or glacial stream comes to light at that place. This is all changed in the country to which these notes refer. When you stand at the point indicated on the map as the source of any western river, you for the most part find no water-course, no water, and can form no idea of where the water comes from. When you do find a " river" you soon learn that neither doesitdrain the country it flows through, nor is there any soakage from the river. The physical conditions of the interior are so exceptional that one must be familiar with them before any scheme can be proposed to meet all facts observed. The following notes refer to underground waters only, and are made out altogether from personal observation.

Underground Waters.-I take it as proved that the rainfall is largely in excess of water accounted for by soakage, evaporation or the outflow of ricers; otherwise, or as Mr. Russell puts it, we should expect to find at Bourke a river 200 yards wide, and 200 feet deep. The water gets away underground, and the geological history of part, at least, of the interior will explain in what way. By the interior I mean all the country situated west of Dubbo and north of the 33rd parallel. In this country three well-marked and distinct geological areas may be distinguished which for convenience I name as follows :- 


\section{The Great Tertiary Plains or Merri Merri Country.}

II. Siluro-Devonian, or Cobar Giralambone Cointry.

III. Cretaceous or Warrego Country.

The Plains.- The tertiary plains extend from the Bogan to the northern boundary of the colony and are represented to a smaller extent towards the south-west. They are one great alluvial deposit which show the vast amount of material removed by denuding influences from the western slopes north of the 33rd parallel.

The efficacy of denudation for a work of such magnitude may be doubted; but as we find the plains at every known depth composed of materials similar in character to deposits now in course of formation, it wonld be rash to say what might not have been accomplished by erosion in a country which has been above the sea since mesozoic times at the very least. Writing of Le Puy, Dr. Geikie says that his first impression was one of utter bewilderment, and upset all previous estimates of the power of rain and rivers. There is almost no amount of waste and erosion that may not be brought about in time by the influence of frost, springs, rain and rivers. To understand this in our colony, one has only to travel over some of the hundreds of miles of plains in the interior.

If we imagine the present surface of the interior covered with a deposit of impervious clay, to the depth of 200 feet, the plains would beginabout Wellington instead of Dubbo, so far would they encroach on the high lands. The present or Bell River would of course flow on to the plains about the same place and cut a bed for itself on the new surface. Now if a well were sunk through this 200 feet of clay a good supply of water would be found in the old river bed, and further, if this well happened to be sunk on that part of the old river which we know as the "Cataract of the Macquarie" the water would rise to the surface we imagine to exist 200 feet above. Diagram II., will make this clear. There is a bar of rock on the river at this point which would effectually stay the flow, while the impervious clay above would retain the water in that direction. The supply must be practically inexhaustible, for at the place where the river comes on to the new surface, there is the old river bed dipping away, and as capable of absorbing water as if the new deposit never covered it. 
Something like what I have been supposing has actually taken place in the past, with this difference that instead of one old river bed under the plains, at one particular level, we have many and on different horizons, from the fact that the formation of the plains extended over great periods of time.

The permanance of drainage-lines is one of the most remarkable facts in the geological history of continents, and Australia is in no way exceptional in this regard. The erosive action of the western rivers and the forming of the plains may have been at work long before Miocene times, when the whole southern portion of the continent was upraised some 600 feet. At that time-in the hey-day of its youth--the average fall of the Macquarie was much greater than at present, and may be represented by $a-b$ (Diagram I.) As the plains were formed the river occupied levels as $c, d, e$, while at the $a$ level would be unaltered or eroded if anything. An important point to note is that the newer beds all branch from the old ones, as in the case supposed above, and with like results, namely that while some water will flow along the new chaunel, a great deal will still get away by the old bed,

It may be objected that if the plains were formed in the way I explain, we should have not many old river beds at different levels, but one great bed of river drift that has been slowly raised while the plains were formed. We might, I admit, expect something like this, if the rivers deposited alluvium to an equal depth, and at the same time over the whole surface of the growing and gradually spreading plains. Then the river would not leave its channel, as when the latter was raised, the banks and surrounding country would be raised to an equal extent. It is almost needless to remark that this is not at all in keeping with our knowledge of the way rivers work in forming plains and depositing alluvium. The great bulk of the transported matter is deposited on or near the banks, so that in time the river margins and eventually the river, will be above the level of the surrounding country. The effect of this, in the end, is to alter the course of the river, only to begin again the same cycle of change. Thus, during the formation of the plains, we have old river beds, (connected with 
present ones) not only at different levels or on different horizons, but also over separate areas.

If my explanation be the right one, a glance at Diagram II., will show what becomes of the floods that "never come down the river," and will show, too, how all the wells on the plains are down to the river drift, otherwise there is no water. On the plains north of Nyngan I have seen the water, after rain, flow from the banks of the creeks towards a depression, a few hundred yards away, and disappear at such a rate as would make the creek " run," yet the latter was perfectly dry. A vast amount of the rainfall is absorbed in this way that would otherwise reach the surface creeks, and so eventually help to swell the river that would then be flowing by Bourke. At Mullungudgeree and other places the water rises in the wells on the old river drift. After the reference to the "Macquarie Cataract," further explanation of this is unnecessary.

I may observe that $I$ have examined a great number of wells of quite another class from any referred to in this paper. They give good water for a time only, and have been called "surface wells." They are sunk in pans or beds of sand that occupy depressions in the clay. The water is merely surface water absorbed by the sand.

Giralambone Country.-The Cobar Giralambone country consists of inclined silarian slates and schists, with patches of devonian lime and sand-stones. The whole area (100 to 150 (?) miles square) is considerably elevated above the plains. Bare and jagged peaks stand out over the general level. Nowhere, as far as I have seen, is the bed-rock at any great distance from the surface. The conditions under which we should expect to find under-ground waters here and on the plains, evidently differ as widely as the geology of the two districts.

Warrego Country.-Of the Cretaceous or Warrego country I cannot at present speak from experience. But it is clear to every geologist, from what is known of Cretaceous rocks, that as regards underground waters we are justified in separating the areas where these rocks occur, from both the Great Tertiary Plains and the Cobar Giralambone country. 


\section{$2 \mathrm{BHL}$ Biodiversity Heritage Library}

Curran, John Milne. 1885. "Notes on the geology and water supply of the interior of New South Wales." Proceedings of the Linnean Society of New South Wales 10, 233-236. https://doi.org/10.5962/bhl.part.17919.

View This Item Online: https://www.biodiversitylibrary.org/item/30482

DOI: https://doi.org/10.5962/bhl.part.17919

Permalink: https://www.biodiversitylibrary.org/partpdf/17919

\section{Holding Institution}

MBLWHOI Library

\section{Sponsored by}

MBLWHOI Library

\section{Copyright \& Reuse}

Copyright Status: NOT_IN_COPYRIGHT

This document was created from content at the Biodiversity Heritage Library, the world's largest open access digital library for biodiversity literature and archives. Visit BHL at https://www.biodiversitylibrary.org. 